\title{
XXVII. On the apparent elevation of objects above the horizon
}

\section{Professor De Luc}

To cite this article: Professor De Luc (1802) XXVII. On the apparent elevation of objects above the horizon, Philosophical Magazine Series 1, 12:46, 148-153, DOI: 10.1080/14786440208676041

To link to this article: http://dx.doi.org/10.1080/14786440208676041

曲 Published online: 18 May 2009.

Submit your article to this journal $\sqsubset \pi$

Џ Article views: 2

Q View related articles $\sqsubset$ 


\section{$\left[\begin{array}{lll}148 & \end{array}\right.$}

XXVII. On the apparent Elevation of Objects above the Horizon. By Profelfor Ds Luc*.

I

$T$ is well known, that on the borders of lakes, the banks of broad rivers, and the fhore of bays, a certain optical illufion often takes place when the fpectator is ftationed in a high point of view. The oppofite bank, under certain circumftances, is feen as it were floating in the air; and this phænomenon is afcribed to refraction: but in my opinion it proceeds from a different caufe.

About two years ago Iobferved the phænomenon in queftion in one of thafe extenfive turf moors that occur fo often among the heights in Bremerlande, through which $I$ was then travelling. The trees which bordered this moor, towards the horizon, appeared to me to be foating in the air. I at firt conjectured, according to analogy, that there muft be a lake or river at the end of the turf moor; but the poftillion who drove the carriage aftured me that this was not the cafe.

In the month of July this year, being in the fame diftrict, I faw a fimilar phænomenon, and under circumftances which induced me to exanine it with more attention. I was on the road between Bremervorde and Brederkefa, proceeding in a north-eaft direction. It was about mine in the morning; the heavens were covered with light clouds, yet the fun appeared through them a little behind me on the right, and over a turf moor which extended to the horizon, and was bordered with a row of trees. When the phrnomenon firft appeared, I was travelling down an eminence on a road adjacent to the edge of the moor, which entered it a little way, and then proceeded up an oppofite hill. The variations which I obferved in the phrnomenou as I advanced flowly down the hill, induced me to difmoun, that I might be able every now and then to turn back. What I obferved on this occafion was as follows :

At the moment when I was about to defeend, I could fee and obferve from the highett point of the hill a very large furface of the turf moor, which extended itfelf with increafing breadth towards the horizon; the diftance of which I eftimated at a German mile. From this pretty high point of fight, I could perceive that the trees at the extremity of the moor did not ftand exactly in a line, but that they formed a fort of wood, which extended backwards on the other fide,

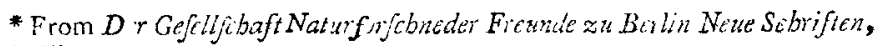
vol. iii. I80 I. 
and, on the fide next to me, had fome projecting curves, but in fuch a manner that the row feemed uninterrupted and continued.

The firft thing that ftruck me as I defcended, was, that at the bottom of this row of trees, and near the extremity which was oppofite to me, there appeared an aperture where there feemed to be no trees, and where I thought I could perceive the heavens under a line of trees which I confidered as further diftant, becaufe their colour was not fo dark, and becaufe they appeared fmaller than the trees of the firlt row between which I faw them. This feparated part of the row feemed to be completely floating in the air; the horizon in the interval of the trees of the firft row was bounded by the furface of the turf moor, and I imagined that I faw the heavens between this extreme furface of the moor and the row of the molt diftant trees.

It was at this moment I alighted: I then turned back, afcended the hill a little, and faw the trees which attracted my attention gradually afume their former appearance. The whole feparated part again funk down to the earth, recovered their former dark colour, and alfo their former height; fo that I was fearcely able to diftinguifh this part from the re. mainder of the row. Some traces, however, of the former transformation remained. I was therefore induced to examine the whole row throughout with the greatef attention; and, on doing fo, I imagined that I obferved fome parts which lay a little more in the back ground, and which, as I conjectured from certain figns, would appear transformed in the like manner when viewed from a fomewhat low point of fight. In regard to the loweft ground line of the row of trees, it appeared, on account of the diftance and thicknefs of the atmofphere, too undefined to perceive bendings in it: I was not able to obferve the trunks of the tiees, which I diftinguifhed from the furface of the moor merely by its brown colour being rendered lefs pale by the intervening fratum of air, by the trees having a higher pofition, and by their being feen through a purer titratum of the atmofphere. On again defcending, I faw thofe parts of the row which I confidered as the moft remote, gradually raife themfelves above the horizontal plain; fo that they feparated themfelves from the row in which they fiood, and feemed to float in the air behind the row which now had the appearance of being bruken. When I reached the valley, where I was however fomewhat elevated above the level of the moor, thefe phrnomena began ta appear in the foremolt row, where the firft breaking appeared. I again thonght I faw the heavens below the trees at the ex- 
trense edge of the moor. Thefe trees alfo appeared to be floating in the air, but they did not elevate themfelves above the ground fo much as thofe $i$ firft oblerved. As I advanced further in the valley, my horizon did not any more change in a perceptible manner; though my pofition in regard to certain parts of the row of trees was confiderably altered, which produced feveral asodifications of the phenomenon. The elevation of the trees above the borizonta! furface increafed the furth $\mathrm{t}$ I I proceeded, but gradually decreafed in thole parts fron which 1 receded, and where it had firtt begun, and at leveth the whole difappeared when I afcended the oppofite hiil.

This circumftance of the phænomenon led me to an obfervation, from which I concluded that refraction had no Alare in it. The maffes of the diftant trees which raifed themfelves from the ground, were fituated between parts of the foremoft rotw, which for a confiderable time did not change their pofition; and thefe unchanged parts gave me fixed points, by which I was enabled to eftimate the elevation of the objects; and it was this eftimation which conducted me to a knowlertge of the nature of the phrnomenon.

The intervats where, in confequence of my progreffive motion: forwards, the heavens appeared under the moft diftant trees; raifed theinfelves mare the lower my ftation became on the hill, and the further I advanced in the valley: but the fummits of the floating trees were not elevated ; on the contrary, they feemed fonewhat depreffed in comparifon of the foremoft trees. The mafips became fhortened below, but at the top they remained on the fame level. I had fufficient opportunity to confirm this circumftance, as, by changing my pofition in a vertical and horizontal direction, I faw three different mafles fo totally difappear, that, in the interval whieh they before occupied in the row of trecs, nothing more was to be feen but the pure heavens. On one of thete mafles difappearing in this manner, when I retired back from my pofition, there firft appeared towards the heavens fome brown fpots, which were the higheft fummits of tbe trees; and the more I receded, the more it feemed as if a curtain dropped down which conceated the part of the heavens before feen: But with whatever attention I looked towards the fpot where this curtain fell down, and where the furinmits of the trees at length difappeared, I could obferve nothing but the pure heaveus. Had a perfon, without fufpecting any thing of this optic transformation. feen from the valley the row of trees in tise horizon evidently broken, and bad again feen from the hill without outerving the gradual chang? 
suring the time of advancing, the fame row once more in the horizon entirely whole, without any interval or break, he would certainly not have believed his own eyes.

Between this phænomenon and that where the coafts appear elevated in the like mannes, I could obferve no difference in regard to the caufes which produce them; and the fame identity is applica'ble to thofe phrnomena which I obferved in another moor in the fame neighbourhood about two years before; only that the trees which formed the horizontal boundary ftood actually in a line, fo that the whole row feemed floating in the heavens at once, and not in portions at a time. All thefe phrnomena then are identically the fame, and it follows from the circumftances here defcribed, that they do not depend on refiaction. The caufe alone lies in the rays of light reflected from the vapours, which in confequence of this reflection appear fo dazzling to the eye, that they conceal the objects fituated below, and prefent the fame appearance as the heavens. The fun, as already faid, was towards that fide where I faw the phænomenon, and his altitude was confiderable, as I obferved the above transformation on the 18th of July, between the hours of 9 and 10. While I obferved from the valley feveral of thefe broken parts of the firft row of trees, the fun was in a perpendicular direction over them. The elevation of the maffes above the ground increafed in general more and more as my fituation became gradually lower, and according as each mafs of the objects to be changed approached nearer to a perpendicular pofition under the fun, in confequence of my advancing in a horizontal direction. As I defcended, I had between me and the objects a ftratum of the atmofphere, which was always denfer, and confequently more proper for reflecting the rays. When I advanced in the horizontal plain, this reflection tock place more in a ftraight line; and when I came into fuch a pofitior. that the vapours threw back the rays of light to the level of the fummits of the moft diftant trees, I faw nothing but this luminous vapour, which loft itfelf in the beavens, and formed with them one continued field, When $I$ had reached the loweft point of the plain, where I found a favourable point of view, fome of the foremott trees could then raife themfelves from the ground, becaufe they were nearer to me; and to compenfate for this greater proxinity, the rays of light muft have penetrated a much thicker ftratum of the atmosphere, and muft have proceeded from a point fo much nearer the perpendicular pofition under the fun.

The prefence of the fun is the principal condition of this 
phænomenon: without the action, of the fun's beams, the vapaurs would not be denfe enough to conceal the objects : it is by means of the folar rays that they are made to difappear from the eye. Thefe rays, however, can be tranfmitted to the eye only under a given angle, in the fame manner as a certain angle is required in order to produce the rainbow by refraction. The ftratum of air which is fufficiently denfe to effect this reflection of the fun, rifes to a certain height, but it can be perceptible to the eye only when the vapours actually throw back a great number of rays. As foon as the point of fight correfponding to this effect is obtained, the eye fees only the fhining vapour, which it cannot diftinguifh from the heavens. This difappearance, however, takes place in regard to diftant as well as to near objects, and rather at the lower than the upper part of the object, becaufe, in the firft cafe, the direction of the line of fight paffes through a larger mafs of vapour, and in the fecond through a denfer ftratum. The lefs denfe part of the vapour, which did not reflect rays of the fun, but which always grew denfer the lower my ftation became, acting like a veil, which interpófed itfelf between my eye and the trees which had not yet difappeared, made me obferve their diftance, and contributed to caufe the elevated trees to appear as if floating behind the row,

In regard to the circumftance that the tops of the diftant trees did not raife themfelves above thofe of the foremoft, though their lower parts feemed to rife above the ground as I defcended, and that thefe tops on the contrary feemed fomewhat depreffed; it arofe from the decreafe in the elevation of my point of ftation having a greater ratio to the lefs diftant than to the moft diftant trees; by which means, the former were raifed more in the fame proportion above the horizon.

When this phrnomenon is obferved on the banks of large pieces of water, and when the objects are at different diftances from the obferver, the truth of the principles here advanced may be confirmed by remarking, that the phrnomenon is modified by a change of pofition; but if the obferver can move about in a horizontal direction, it will be of great ufe to obferve the changes of the object in a vertical direction, fuppofing he bas opportunity, on any gradual declivity, of afcending and detcending. If the vertical meafurement of the objects then changes, fo that their total height decreafes the more the objects feem to rife from the ground when the obferver defcends the declivity, this is a iufficient proof that the whole image is not elevated, but that 
its loweft part difappears from the eye, behind a mafs of vapour fo condenfed that it cannot be diftinguifhed from the fky above or the water below.

I entertain no doubt, that this is the real caufe of all the phænomena of this kind, as I have never been able to comprehend how fuch phænomena could be produced by refraction.

When the objects which are feen under water appear elevated in different degrees, it may be readily conceived that the rays of light proceed from the water, which is very denfe, into air, which is much rarer. When we fee the celeftial bodies above the horizon, while they are actually below it, we may eafily conceive that the rays of light, proceeding in an oblique direction, fometimes pafs through rarer and fometimes through denfer ftrata of the atmofphere. But, in the prefent cafe, there is no difference in the fpecific denfenefs or rarity, and the correfponding power of refraction of the medium through which the ray of light is tranfmitted to the eye; and if an actual elevation takes place by refraction, the action muft be equally great from water or from a lake, and on the ubjects oppofite to them: confequently the whole mars of thefe objects muft appear equally elevated, without any interruption being obferved in them.

I fhall here add, that I have been very often deceived in thefe moors, fo that $I$ thought I faw at a great diftance lakes and rivers, where my drivers affured me there was nothing of the kind. This was always the cafe in the morning, and when the fun by ftanding over the object gave rife to the illufion. Had not the horizon on thefe occafions been bordered with a row of fmall hills, I thould certainly have believed that I faw not only a piece of water, but even the heavens. The hill prevented me from feeing at one view the heavens and the luminous vapour, and the vapour feen alone appeared to me as an extended piece of water illuminated by the reflection of the heavens.

XXVIII. Defcription and Natural Hifory of the Wild Goat of the Alps. By M. Berthout Van Berchem jun.* 7 $\mathrm{HE}$ wild goat of the Alpst is fill little known to naturalitts, though mentioned by feveral authors. As it lives on the

* From Memoires de la Socizté des Sciences pbyfiques de Laujanne, vol. ii.

tCapra ibex, Erxleben Sift. Reg. p. 26: Linn. Hift. Nat. p. 95 . Le Bouguetin, Buffon, vol, xii. p. 136 . 